\title{
Study on Monitoring Problems and Solutions of South China Karst
}

\author{
Zhenzhen Zhang ${ }^{1, a}$, Kangning Xiong ${ }^{1, b}$ and Shizhen Xiao ${ }^{1, c}$ \\ ${ }^{1}$ School of Karst Science, Guizhou Normal University, 550001 Guiyang, P.R. China \\ a zzz3521@163.com, biongkn@163.com, c 34987169021@qq.com
}

Keywords: Natural World Heritage; monitoring; South China Karst.

Abstract. As a natural World Heritage site, South China Karst is located in one of the major karst areas in China. Due to the impacts of natural factors and human socio-economic activities, its ecosystem is fragile and deteriorating. It is important to study whether the impacts are affecting the outstanding universal value and sustainable development of the heritage site. From a scientific and systematic study on the current situation, questions and a sector monitoring plan of South China Karst, a field trip of seven sites of South China Karst, seminars, research, expert advice, etc., we identify the main problems of monitoring in South China Karst World Natural Heritage. Those problems include the lack of a unified monitoring system, unsound monitoring indicators, non- targeted monitoring indicators, the absence of professionals and equipment, aging equipment, among other things. To solve these problems, we recommend establishing a collaborative monitoring system, providing a full set of monitoring indicators, developing monitoring plans, supplementing facilities and equipment, improving monitoring network surveillance and establishing a feedback mechanism of monitoring results to ensure that the outstanding universal value of South China Karst World Natural heritage is sustainably preserved.

\section{Introduction}

Comprehensive monitoring of World heritage properties is an international requirement. The World Heritage Committee has recommended development of a management framework for effective coordination between the different parts of the property and urged the State Party to continue efforts to integrate planning, governance and management across the whole South China Karst World Heritage property, including finalization of a management plan anticipated by 2015.

It is the duty of China, one of the State Parties and an important country in terms of World Heritage, to fulfill the commitment of good protection and management of the heritage property to UNESCO ${ }^{[1]}$. It is also one of the requirements to enhance the level of protection and management, improve the capacity of disaster and risk prevention, so that the authenticity and integrity of South China Karst World Natural Heritage can be preserved sustainably.

\section{Situation Analysis}

Monitoring Content and Key Indicators. Based on the resources, protection status and management requirement of the heritage properties, the protection and management institutes of South China Karst have respectively set up a series of monitoring indicators. These indicators include World Heritage value, heritage presentation, environmental factors and threats (Table1).

South China Karst World Natural Heritage Departments have established indicators and monitoring systems, which is in accordance with characteristics of all World Heritage sites. We can take South China Karst Phase II as an example:

The main monitoring indicators of Guilin karst are surface water quality atmosphere quality, monitoring of noise, species and numbers of animals and plants, ecological environment (mainly in Lijiang), biodiversity and dynamic change, numbers and sources of visitors, prevention of human-caused forest fires, change in soil physical and chemical properties, population and land use conditions in the nominated areas and buffer zone, monitoring of community participation, oxygen and carbon isotopic characteristics of rainwater, drip water and presence of speleothems in a cave, 
amphibians and reptiles in Lijiang National Park, impact of community development project on protected areas, karst collapse and karst carbon sink.

The main monitoring indicators of Shibing karst are karst process, species and numbers of animals and plants, water quality monitoring, change in soil physical and chemical properties, weather and climate condition, change of usage of land, numbers and sources of visitors, sightseeing district tourism and entertainment facilities, tourism project, forest diseases and insect pests, forest fire prevention of human-caused forest fires, community demographic data and boundary of protected area.

The main monitoring indicators of Jinfoshan karst include integrity of Jinfoshan karst (distribution, boundary, type), quantity and soundness of Jinfoshan attractions, vegetation, plant species and quantity, animal species and quantity, alien species and harms, atmospheric quality, hydrological dynamics, water quality, soil erosion, village and residents population in the nomination and buffer zone, extent of arable land, land use status in nomination and buffer zone, tourist resorts, entertainment facilities, geological hazards, surface and underground water quality and water quantity, air quality, rare animal population dynamics, ecological environment (mainly in Jinfoshan), biodiversity of animals and plants and its change over time, forest fire monitoring, visitation, impacts of community development projects on protected areas and scenic areas, and community co-management and participation level.

The main monitoring indicators of Huanjiang karst scope and acreage of Mulun National Nature Reserve of Guangxi, development status of cone karst landforms, structure and function of forest ecosystem, forest biodiversity and dynamic change, animal species and quantity, plant species and quantity, social and economic development, impact of community development projects on nature reserves, monitoring of community development and participation level, changes in usage of land, forest pests diseases, forest fires, monitoring on water and air quality, basic condition of community (village, resident population, ethnic, farmland area ), firewood requirement and grazing.

Table 1 Common monitoring indicators of the South China Karst

\begin{tabular}{|c|c|}
\hline $\begin{array}{l}\text { Monitoring } \\
\text { programs }\end{array}$ & Common monitoring indicators \\
\hline $\begin{array}{c}\text { World } \\
\text { heritage value }\end{array}$ & $\begin{array}{l}\text { Geomorphologic landscape, flora and fauna and their habitat, species variation, } \\
\text { integrity of the boundary of property and buffer zone }\end{array}$ \\
\hline $\begin{array}{l}\text { Heritage } \\
\text { presentation }\end{array}$ & $\begin{array}{c}\text { Visitation numbers, visitation structures, areas of site seeing for individuals, tourism } \\
\text { service facility numbers and quality }\end{array}$ \\
\hline $\begin{array}{l}\text { Environmental } \\
\text { factors }\end{array}$ & Climate change, air water and soil quality, noise, and environmental sanitation \\
\hline Threat factors & $\begin{array}{c}\text { Meteorological disasters, forest fires, invasive alien species, drought and flood, } \\
\text { mud-rock flow, ground sinking, earthquakes, insect infestations, illegal hunting and } \\
\text { land use, etc. }\end{array}$ \\
\hline
\end{tabular}

Existing monitoring systems. There are two working monitoring mechanisms operating in South China Karst World Natural Heritage sites: in-house monitoring by the responsible managing organization, or commission monitoring by an outside agency. Management protection organizations of each property are currently responsible for regular monitoring in such fields as forest fire prevention, invasive alien species, visitation numbers and structure, areas of site seeing, number and quality of tourism service facilities, resident population and social and economic conditions. Some other indicators are best monitored by outside agencies or institutions, regularly or irregularly, due to lack of specialists or monitoring equipment within the local management body ${ }^{[2-3]}$. For example, geology, air and water environmental as well as bio-monitoring will be conducted by official forestry and environmental conservation organizations. 
Several monitoring methods have been used in all of these four components, such as fixed-point observation, instrument monitoring, community patrol monitoring, survey and statistics. Each station of the heritage management agencies is equipped with monitoring guards, who are responsible for forest fire prevention, disaster relief, illegal hunting, illegal felling of trees, among others.

Data collection points regularly submit data to the relevant departments, and also commission research institutes and universities to analyze data for obtaining solutions or suggestions of current problems.

Up till now, the surface water sampling and monitoring results of South China Karst World Natural Heritage properties are in line with the first and second class limitation of Environmental Quality Standards for Surface Water (GB3838-2002); Air quality reaches first class limitation of The Air Environmental Quality Standards (GB3095-2012); acoustic environment meets the 0 class condition of Standard of Environmental Noise of Urban Area (GB3096-2008); and soil quality measures up with the first class limitation of Environmental Quality Standard for Soils (GB156181995).

\section{Issues, Threats and Challenges}

Based on the standards required for World Heritage properties, research, conservation, management and monitoring by, South China Karst World Natural Heritage has established a variety of monitoring indicators, with the relevant personnel and equipment to carry out a number of monitoring activities. However, the monitoring mission of the property has identified the following gaps, threats and challenges.

Absence of a unified monitoring system. As a serial property, South China Karst lacks a unified monitoring system, and instead has a series of independently set monitoring factors. This is the main obstacle for comparing, analyzing and archiving the monitoring indicators. In this context, the monitoring results cannot be fully used and this limits the role of monitoring to promote the protection and management of South China Karst. Especially, a better linkage mechanism between the Libo Karst and Huanjiang Karst sites demands prompt establishment and perfection ${ }^{[4]}$.

Imperfect monitoring indicators. The monitoring indicators of heritage sites are not sound, and some are not targeted and do not reflect the current protection and management situation of the heritage. This may mislead protection and management decisions.

The influence of infrastructure construction in Shilin karst and Libo karst are of concern. For example, Shilin karst plans to broaden and build roads across the buffer zone of the heritage site to connect Changhu Scenic, Dieshui Scenic and Shilin County. Libo karst plans to build a north-south high-speed railway tunnel, which will impact the hydrogeological environment. These factors should be carefully considered.

Wulong karst is located in the Yunnan-Guizhou Plateau and the joint position of the Three Gorges region, which is prone to collapse, landslides, mudslides, karst collapse and earthquakes, which makes it a very hazardous area. The work of the various monitoring and control of geological disasters should be strengthened, adhering to the "prevention first, combining prevention and comprehensive management" concept and the development of early warning for disaster prevention measures; protect against potential disaster area by reinforcement, take regular checks on dangerous rock, and establish early warning signs in the necessary places; and widely propagandize and popularize disaster prevention knowledge to the public to enhance the prevention awareness. In summary, Wulong karst is a geological disaster-prone area, and its geological disaster warning lags behind, what is required.

There are intense human activities in Guilin Karst. Restricted by many factors, the property lacks monitoring indicators and related monitoring plots, such as the impact of urbanization and infrastructure construction on heritage protection.

Some protective measures are ineffectively used in Shibing karst, for example, ecological sewage treatment pond is not well used. The property has only part of a routine monitoring program, and 
lacks a monitoring plan for special events, such as the impact of heavy rain on the Shanmu River water quality and waste emissions to the river system.

Jinfoshan karst lacks monitoring indicators for cave system development and evolution. In addition, the presence of mineral development in the southwestern part of Jinfoshan karst cliffs and the building of hotels and other tourist facilities in the property should also be among the key elements that are monitored.

There is also a failure to record changes in the types of invasive species, the number of weed plant and pest animal communities, biomass and coverage, data on species invasions have gaps, while deforestation and burning of straw still exist.

Lack of professional personnel and equipment. Due to the influence of administrative regions, management mechanisms and other factors, the professional personnel and professional monitoring facilities of Guilin karst appear to be ill-defined. The monitoring facilities are not modern. There are few monitoring stations and monitoring points in Shilin karst, Libo karst and Jinfoshan karst, and there is an incomplete coverage of monitoring stations. In Huanjiang karst and Wulong karst, monitoring facilities are inadequate and technologically deficient.

\section{Strategy and measures}

Establish a united monitoring system of South China Karst. South China Karst is composed of Shilin Karst in Yunnan Province (Phase I), Libo Karst in Guizhou Province (Phase I), Wulong Karst in Chongqing City (Phase I), Guilin Karst in Guangxi Zhuang Autonomous Region (Phase II), Shibing Karst in Guizhou Province (Phase II), Jinfoshan Karst in Chongqing City (Phase II) and Huanjiang Karst (Phase II) as an extension of Libo Karst also in Guangxi Province.

South China Karst has now established a Conservation and Management Coordination Committee for South China Karst World Natural Heritage, which is responsible to collaborative management of the seven clusters of the serial property. Given the South China Karst realities and UNESCO requirements, combined with the "Chinese World Cultural Heritage Monitoring Inspection management approach" by the National Administration of Cultural Heritage of the 20th executive meeting examined and adopted on 8th December, 2006, with reference to the successful experience of the Grand Canal Monitoring, the monitoring and early warning system of South China Karst World Natural Heritage could adopt a "two-platform, three-level management" system to implement a South China Karst coordinated warning monitoring network (Figure 1).
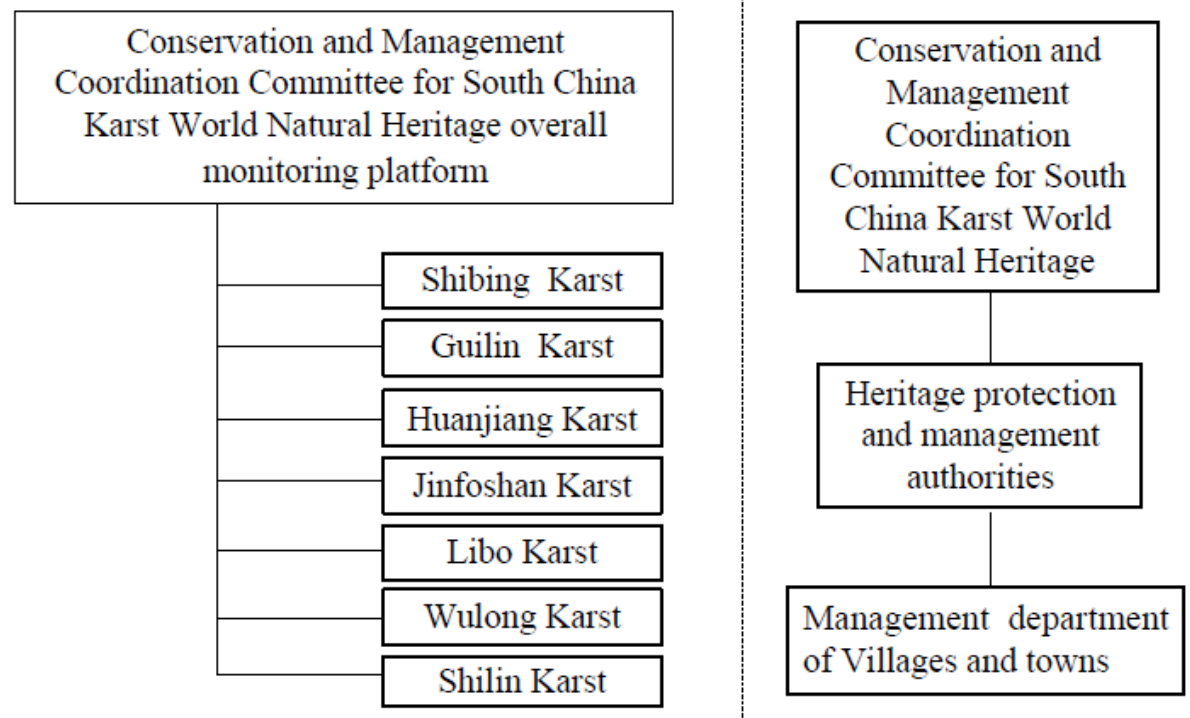

Figure 1 “Two-platform, three-level management” mechanism 
A two-platform system would consist of a Conservation and Management Coordination Committee for South China Karst World Natural Heritage, with an overall monitoring platform and sub-platform for each heritage site. Three-level management would require a Conservation and Management Coordination Committee for South China Karst World Natural Heritage, the protection and management institute in World Heritage sites and sections of villages and towns involved in the property. The Conservation and Management Coordination Committee for South China Karst World Natural Heritage would be responsible for: formulating principles, policies, management systems and technical specifications of the monitoring mission; organize or commission a professional organization to implement reactive monitoring; and organize inspections. Heritage agencies of environmental protection, forestry and other departments would be responsible for monitoring this area of the world natural heritage, reaction monitoring, and regular or irregular inspections. This system involves shared resources, early warning processes and cross-sector synergies, along with other advantages.

Enrich the monitoring factors and improve monitoring plan. Each site in theproperty has aesthetic landscape and geological features and other aspects of outstanding universal value, which together constitute the evolutionary sequence of the South China Karst. Thus, there are some common threats and challenges, and a need to establish common indicators for these problems, together with unified monitoring, strengthened exchanges and better cooperation among the sites. Water pollution mentioned in the IUCN monitoring report, and increasing tourism infrastructure are common problems of sites in South China Karst which need improved monitoring. Other outstanding problems in each site are listed in Table 2.

Table 2 Specific key monitoring indicators of South China Karst sites

\begin{tabular}{cc}
\hline Heritage sites & Distinctive monitoring indicators \\
\hline Shilin Karst & Stony desertification, rock erosion rate, collapse \\
Libo Karst & Tourist facilities \\
Wulong Karst & Collapse, landslide, mud-rock flow, karst collapse, earthquake and other \\
geologic disasters
\end{tabular}

Supplement and improve facilities and equipment. There should be standardization of scientific instruments, information technology to ensure an efficient and effective monitoring system for the South China Karst. There should also be adequate field staff and field inspections using proper equipment, such as Outlook equipment, located ecosystem observation equipment, cave biological survey equipment, foci of disease monitoring equipment, fire command vehicles, and motorcycles.

The South China Karst World Natural Heritage Site should have around the clock video surveillance patrol remote systems, a rational distribution of surveillance cameras to ensure monitoring of heritage sites covering large areas. Also required are: network video transmission technology, digital video signal in real-time transmission to the monitoring center server, regulators through a standard Web browser, remote viewing graphic image data, and real-time monitoring information collected for analysis, storage, retrieval, backup and filing .

Modern information technology should be employed to achieve dynamic monitoring data collection, and effective interaction of automated assessment and emergency treatment. A South China Karst monitoring and early warning platform as is shown in Figure 2 should contain a .NET technology framework, in accordance with a standard unified platform, unified data, unified technology, unified user, integrated and systematic construction principle ${ }^{[5]}$. Better systems of 
heritage information management are required, along with heritage GIS capability, monitoring and early warning systyems, decision support and public information systems, improved databases, archives management, early warning systems, evaluation and decision making, public participation, system management of six modules, integrated building monitoring system, video monitoring system, and a KPI performance management system ${ }^{[6]}$.

In addition, thematic information databases should be established, such as: Biodiversity Conservation and Biogeographic Information System including environmental factors, ecological systems, and endangered species, classified specimen collection and genetic resources information systems $^{[7]}$. Also required are collecting and processing related to the spatial distribution of taxa, by means of a GPS (Global Positioning System) or BDS (Beidou satellite navigation system), computer technology, for improved and updated taxa of the Geographic Information Database. The system can be used to query, retrieve, provide statistics, records management, and foreign exchange and subsidiary protection management decision-making information.

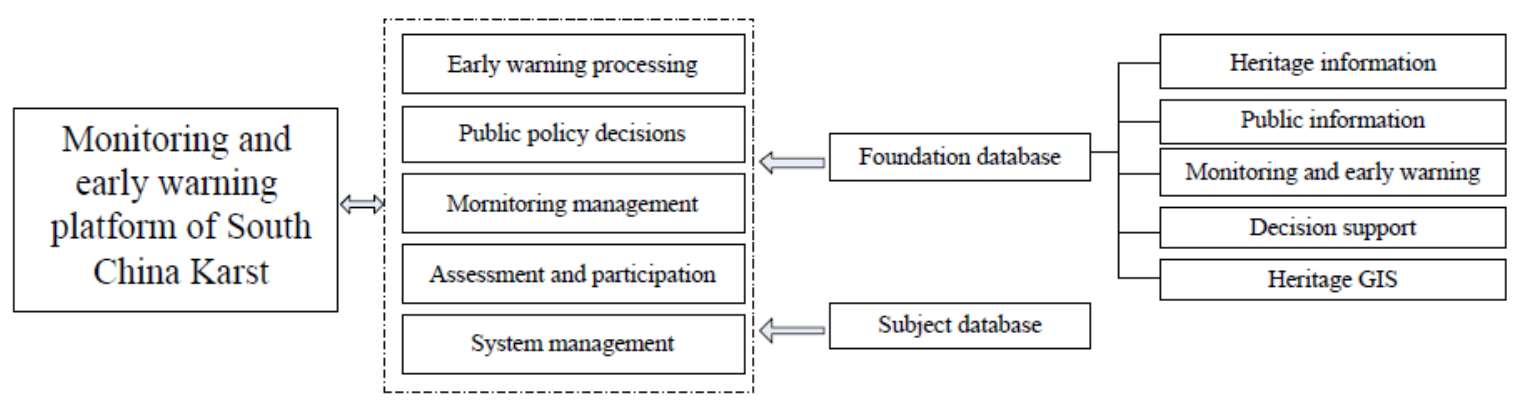

Figure 2 Monitoring and early warning platform

Computer network communication, management information system technology is a means to satisfy the heritage resource protection and management requirements of the decision support system, including an information resource, transmission network, scientific decision-making and real-time scheduling ${ }^{[8-10]}$. There is a need to formulate a "South China Karst World Natural Heritage Monitoring and Warning Implementation Guide" (hereinafter referred to as "Guide"), to provide the reference and basis for monitoring and early warning work of the South China Karst. According to "Guide", we must establish a professional monitoring and evaluation mechanism and provide for its scientific management. At the same time, the introduction of professional monitoring personnel, regular professional training monitoring and early warning knowledge, learn from the experience of the United States, relevant experience inside and outside the World Natural Heritage monitoring and evaluation, monitoring and management mechanism to encourage innovation. We must also strengthen the monitoring department of personnel management, to ensure a good monitoring system for protection.

For community participation there must be public knowledge of monitoring and evaluation, and the monitoring results should be published annually ${ }^{[11]}$. A coordinated communication mechanism is necessary to encourage community residents through photographs, video, text records, anonymous upload a variety of ways to participate in monitoring and early warning, monitoring the implementation of the monitoring.

Establish monitoring feedback mechanisms. The establishment of the South China Karst monitoring database and network platform, where all relevant departments upload the updated database information in a timely manner, allows for timely monitoring results of sorting, reporting, monitoring and evaluation to submit regular reports to the higher authorities,. This is in accordance with the World Heritage Centre request for the preparation of a unified approach in world natural heritage regular monitoring reports. The reports must be comprehensive, and thorough analysis must cover the scope of monitoring, monitoring period, monitoring methods, raw monitoring data, person who is responsible for it, monitoring results, strategies and recommendations. Invited foreign experts 
could monitor the timely analysis of the results, preparation of monitoring and evaluation reports and monitoring results thus providing a feedback mechanism. The management department can propose corrective measures. Ratings based on monitoring results for each of the heritage sites, can become appropriate incentive mechanisms to encourage heritage management agencies to better complete protection management requirements. Then can be set up a South China Karst monitoring database, with messaging platforms and feedback mechanisms of monitoring results.

\section{Conclusions}

Build a unified monitoring system in serial world heritage site. Each part of South China Karst had its own monitoring control indexes, but the geographic locations are far apart and distributed in four provinces, making that these parts have not really connected well on the topics such as monitoring methods, technology, facilities and staff training. The whole monitoring system is still in a primary stage. As South China Karst phase II has been inscribed into the World Heritage list, a united monitoring system is needed to manage these seven heritages sites. The UNESCO World Heritage center also proposed that South China Karst needs to establish a unified agency to manage the conservation of these karst sites. Therefore, not only from the international side, but also from the domestic side, we definitely need to build a unified monitoring system to conduct the scientific monitoring on the heritage sites.

Set up a systematic assessment system. the lack of a unified monitoring system and a focus on monitoring index on conservation of value, monitoring results cannot be assessed effectively. Some of the South China Karst heritage sites neither assessed the monitoring result, nor assessed the result scientifically. That was why all the monitoring results remained only as raw data. The monitoring results were never used and analyzed effectively and not enough value was made of the monitoring program. Also we want to use the monitoring results and analyze each heritage monitoring index, and predict the tendency of the condition of OUV. Under the management of a Conservation and Management Coordination Committee for South China Karst World Natural Heritage, we can build an assessment system and invite local and international experts to assess the monitoring results. Finally, all the experts can report on South China Karst World Heritage monitoring, to complete the monitoring work on the karst sites.

Establish a union of the monitoring feedback system. South China Karst serial property has seven sites. Each site did not report very well, so the monitoring results cannot be treated scientifically. Without a unified monitoring feedback system, no matter what the manager of the heritage or the conservation planning scholars do, the conservation and management planning cannot be done scientifically. To set up a South China Karst monitoring database and network platform, the management department needs to update the database, then to arrange the results and reports, and submit the monitoring reports to the supervising department regularly. The report has to be comprehensive, analyzed completely, cover different periods and all monitoring modes, with original data revealing the responsibility, results, strategies, and suggestions. Then invited local and foreign experts can analyze the reports from each site. Last, but not least, experts can use the reports from the sites to compile a monitoring assessment report. Depending on the expert reports, we can set up a system to encourage each heritage site to improve their work on conservation and management.

\section{Acknowledgements}

This work was financially supported by China National Project for Nomination and Conservation of the World Heritage “The South China Karst World Natural Heritage” (Jian Cheng Jing[2005]No.115 / [2012]No.175, Qian Jian Jing [2005]No.111 / Qian Jian Inscription[2012]No.15).

Corresponding author: Kangning Xiong, Xiongkn@163.com 


\section{References}

[1] Information on http://whc.unesco.org/en

[2] Shizhen Xiao, Kangning Xiong, Ziqi Liu, Qi Liu, Lu Luo and Gaocong Li: International Journal of Geoheritage. Vol. 3 (2015), p. 40-52

[3] Kangning Xiong, Gaocong Li, Lingyu Wang: Chinese Landscape Architecture. Vol. 28 (2012), p. 66-71 (In Chinese)

[4] Ziqi Liu, Kangning Xiong, Gaocong Li, Shizhen Xiao, Lingyu Wang, Hengsong Wang and Ding Luo: Carsologica Sinica. Vol. 33 (2014), p. 64-76 (In Chinese)

[5] Yi Zhang: China Cultural Heritage. Vol. 3 (2014) , p. 88-93 (In Chinese)

[6] Yun Zhang: China Management Informationization. Vol. 7 (2014), p. 73-74 (In Chinese)

[7] Chunyu Shi: Chinese Landscape Architecture. Vol. 9 (2013), p. 117-119 (In Chinese)

[8] Kangning Xiong, Shizhen Xiao, Hu Chen, Li Rong, Jian Peng and Fangjuan Du: World Heritage and Chishui Danxia Landscape (Higher Education Press, China 2012)

[9] Rouran Zhang: City Planning Review. Vol. 35 (2011), p. 36-42 (In Chinese)

[10] Youbo Zhuang: Chinese Landscape Architecture. Vol. 28 (2012), p. 97-100 (In Chinese)

[11]Drost A: Annals of Tourism Research. Vol. 23 (1996), p. 479-484. 